\title{
Jadwiga Izdebska, Dziecko - Dzieciństwo - Rodzina - Wychowanie rodzinne. Kategorie pedagogiki rodziny w perspektywie pedagogiki personalistycznej, Bialystok: Niepaństwowa Wyższa Szkoła Pedagogiczna, 2015,
} ss. 223.

DOI: http://dx.doi.org/10.12775/PCh.2015.019

W obliczu istniejącego wśród badaczy pluralizmu epistemologicznego i aksjologicznego dotyczącego rozumienia podstawowych zagadnień pedagogiki rodziny, konieczne jest podejmowanie rzetelnego i jednoznacznego ujmowania istotnych kwestii dotyczących wychowania w rodzinie w pewne ramy - określonej orientacji, kierunku i nurtu badawczego. Autorka przyjęła nurt personalistyczny pedagogiki jako bazę do rozważań o dziecku, dzieciństwie, rodzinie oraz o wychowaniu rodzinnym.

Na strukturę książki składają się cztery rozdziały, zawierające analizy dotyczące kolejno: zagadnienia dziecka i dzieciństwa (rozdziały I i II), rodziny (rozdział III) oraz wychowania rodzinnego (rozdział IV). Omówioną w rozdziałach problematykę poprzedza wstęp, a wieńczy zakończenie i bibliografia.

Autorka monografii, prof. dr hab. Jadwiga Izdebska, od lat podejmuje problematykę wychowania w rodzinie, ujętą w perspektywie pedagogicznej, zaś jej prace badawcze dotyczą funkcjonowania współczesnej rodziny w dobie przemian społecznych, politycznych, gospodarczych i kulturowych oraz jej dysfunkcjonalności. Autorka podejmuje także rozważania nad sytuacją dziecka w rodzinie, nad nowymi wymiarami obrazu jego dzieciństwa w warunkach globalizacji, a także nad zagrożeniami i wartościami wychowawczymi mediów i multimediów w życiu dziecka.

Zawartość merytoryczna książki jest holistycznym ujęciem zagadnień dotyczących rodziny, dziecka oraz wychowania rodzinnego. Autorka w spo- 
sób przeglądowy prezentuje poszczególne kwestie, skupiając się na przedstawieniu podstawowych założeń pedologii, pajdocentryzmu i pedagogiki personalistycznej. Wskazuje także na etymologię pojęcia dziecko, rozwój zainteresowań nad dzieckiem na przestrzeni wieków oraz charakteryzuje dziecko jako osobę, podmiot, dar, sacrum, wartość, przedstawia jego godność i wolność. Autorka reprezentuje stanowisko, zgodnie z którym „dziecko jest najważniejszą, najcenniejszą wartością, bez niego nie jest możliwy rozwój, trwanie, ciagłość społeczeństw".

W opracowaniu analizowana jest także kategoria dzieciństwa, rozumianego nie tylko jako pierwsza faza integralnego rozwoju osobowego człowieka, ale nade wszystko jako świat dziecka, jego przeżyć, doświadczeń, aktywności i wartości. Autorka przedstawia współczesną sytuację życiową polskich dzieci, nowe szanse i zagrożenia ich rozwoju i edukacji. Wskazuje przy tym na nowe, współczesne oblicze dzieciństwa, które z jednej strony jest dzieciństwem nowych szans i możliwości rozwojowych, z drugiej zaś jest dzieciństwem narażonym na dysfunkcję rodziny, szkoły czy środowiska lokalnego (dzieciństwo dotknięte bieda, przemoca, osierocone, zranione, konsumpcyjne, uzależnione od Internetu, bierne intelektualnie, fizycznie i społecznie).

Życie dziecka jest ze swej natury wpisane w życie rodzinne, które ma swój początek w małżeństwie. Autorka ukazuje podstawowe zagadnienia z obszaru pedagogiki rodziny, zwłaszcza zaś wartość autoteliczną i alloteliczną małżeństwa, kwestie związane z macierzyństwem i ojcostwem. Przedstawia także charakterystykę więzi rodzinnej, funkcji rodziny, struktury rodziny, kształtowania kultury pedagogicznej rodziców przez różne instytucje oraz przemiany współczesnej rodziny. Ukazując właściwości rodziny ponowoczesnej, autorka zwraca szczególną uwagę na aspekty dotyczące między innymi ograniczonego realizowania niektórych funkcji rodziny, dysfunkcjonalności rodziny, rozpadu tradycyjnej wspólnoty rodzinnej bazującej na naturalnej więzi społecznej, transformacjach społeczno-obyczajowych czy przeobrażającej się przestrzeni społecznej.

Omawiając wychowanie rodzinne $\mathrm{z}$ perspektywy personalistycznej, autorka opisuje je jako ukierunkowane na integralny rozwój dziecka jako osoby zdolnej do miłości, który uwarunkowany jest indywidulanymi potrzebami i możliwościami wychowanka. Odbywa się to w atmosferze wzajemnego poszanowania podmiotowości i godności członków rodziny oraz w ich wzajemnych relacjach opartych na dialogu, spotkaniach, interakcjach, otwartości, zrozumieniu i miłości. Omówiona została również specyfika wychowania rodzinnego, jego istota i znaczenie, a także modele wychowania rodzinnego. 
Recenzowana monografia stanowi nie tylko vademecum bazowych dla pedagogiki rodziny zagadnień ujętych w świetle pedagogiki personalistycznej, prezentowanej przede wszystkim w odniesieniach do personalistycznej myśli Jana Pawła II. Jest ona także niezwykle aktualnym przeglądem uwarunkowań - szans i zagrożeń - rozwoju dzieci i rodziny, opisuje bowiem zmiany zachodzące $\mathrm{w}$ XXI wieku związane $\mathrm{z}$ globalizacją, transformacją systemową i mediatyzacją życia społecznego i rodzinnego. Egzemplifikując, autorka ukazuje dzieciństwo medialne jako oblicze funkcjonowania dziecka w świecie zdominowanym przez media elektroniczne, które dzisiaj są jednym z pierwszych instrumentów jego eksploracji. Ponadto przedstawia alternatywne struktury małżeńsko-rodzinne, takie jak kohabitacja, rodzina diasporowa, rodzina bezdzietna $\mathrm{z}$ wyboru, rodzina zrekonstruowana po rozbiciu, małżeństwa byłych księży katolickich, małżeństwa osób młodocianych, małżeństwa osób niepełnosprawnych czy małżeństwa mieszane kulturowo.

Książka stanowi cenną lekturę i jest warta polecenia, zwłaszcza jako podręcznik dla studentów nauk społecznych, szczególnie zaś tych, którzy podejmują się zarówno pracy badawczej w ramach studiów pedagogicznych, jak i praktyki edukacyjnej w formie pracy z dzieckiem i rodziną. Uznana za wartościową winna być również przez rodziców, nauczycieli, wychowawców, duszpasterzy, słowem - wszystkich, którzy z różnych względów troszczą się o optymalny rozwój dziecka oraz o wychowanie rodzinne bazujące na uznaniu autonomicznej wartości osoby.

Marta Samorańska*

\section{Sabina L. Zalewska, Relations and marriage bond in the empty nest syndrom, Warszawa: Wydawnictwo Uniwersytetu Kardynała Stefana Wyszyńskiego, 2014, Ss. 158.}

DOl: http://dx.doi.org/10.12775/PCh.2015.020

Przed przystąpieniem do lektury książki Sabiny L. Zalewskiej warto sięgnąć po Metafizykę moralności Immanuela Kanta. Mimo że wielki filozof z Królewca nie był żonaty ani nie pozostawił po sobie potomstwa, to jednak w paragrafach od 22 do 30 wskazanego dzieła przedstawił, jak mi się

* Mgr Marta Samorańska jest doktorantką w Katedrze Pedagogiki Rodziny na Wydziale Nauk Społecznych Katolickiego Uniwersytetu Lubelskiego Jana Pawła II. Adres: In- 